\title{
Significance of enzyme linked immunosorbent assay (ELISA) for antibodies to double stranded and single stranded DNA in patients with lupus nephritis: correlation with severity of renal histology
}

Mikio Okamura, Yoshiharu Kanayama, Koji Amastu, Nobuo Negoro, Shinichi Kohda, Tadanao Takeda, Takatoshi Inoue

\begin{abstract}
The correlation between renal histology and class specific (IgG and IgM) antibodies to double stranded DNA (dsDNA) and single stranded DNA (ssDNA) was studied by enzyme linked immunosorbent assay (ELISA) in 40 untreated patients with systemic lupus erythematosus (SLE). The levels of IgG antibodies to dsDNA were significantly higher in patients with World Health Organisation class IV nephritis than in those with class I, class II, or class III nephritis. IgG antibodies to ssDNA were higher in patients with class IV than in those with class II nephritis. IgG antibodies to dsDNA showed a close correlation with the histological activity score and the amount of electron dense deposit. IgG antibodies to ssDNA showed only a weak correlation with the renal histological activity score. IgM antibodies to dsDNA and IgM antibodies to SsDNA were not correlated with renal histological features. Patients with moderate to severe nephritis had a lower ratio of IgM antibodies to dsDNA to IgG antibodies to dsDNA than those with mild nephritis. These results indicate that the measurement of IgG antibodies to dsDNA is predictive in evaluating renal histological activity in patients with SLE.
\end{abstract}

(Ann Rheum Dis 1993; 52: 14-20)

Antibodies to double stranded DNA (dsDNA) are characteristic of systemic lupus erythematosus (SLE), 12 and these antibodies have been considered to be the principal factor in the pathogenesis of lupus nephritis. ${ }^{34}$ Many workers have reported a significant correlation between serum titres of antibodies to dsDNA and the severity of the disease, particularly associated with lupus nephritis. ${ }^{1}{ }^{5-7}$ Relatively few studies, however, have examined the correlation between antibodies to dsDNA and the histological severity of lupus nephritis. . $^{8-10}$ Although Steinman et al, using a synthetic double stranded copolymer of deoxyadenosine and deoxythymidine to detect antibodies to dsDNA, showed a significant correlation between serum titres of antibodies to dsDNA and renal histological severity, ${ }^{10}$ other workers using a conventional dsDNA preparation to detect antibodies to dsDNA, could not confirm this. $^{89}$

An enzyme linked immunosorbent assay (ELISA) for antibodies to dsDNA is a sensitive and specific method for their detection and measurement, ${ }^{11} 12$ and also for the measurement of antibodies to single stranded DNA (ssDNA). ${ }^{11}{ }^{13}$ An ELISA offers the opportunity to measure the different antibody classes and to avoid the measurement of non-specific DNA binding proteins. Using a chromatographically purified and S1 nuclease treated dsDNA preparation as the solid phase antigen, we used an ELISA for the measurement of antibodies to dsDNA of the IgG and IgM classes and assessed the correlation between serum levels of antibodies to dsDNA and histological severity in 40 untreated patients with SLE. Although antibodies to ssDNA have been thought to be associated with disease activity in patients with SLE,${ }^{14}$ no study has correlated them with renal histological severity. We have examined this and appraised the significance of each parameter in evaluating renal histological severity in patients with SLE.

\section{Patients and methods}

PATIENTS

Serum samples were obtained from 40 patients with a clinical diagnosis of SLE at the First Department of Internal Medicine, Osaka City University Hospital. All patients met the 1982 revised criteria for the classification of SLE. ${ }^{15}$ None of the patients had received steroids or immunosuppresssive drugs at the time of collecting the serum samples. The serum samples were stored at $-80^{\circ} \mathrm{C}$ until tested. A renal biopsy sample was taken either at the pretreatment stage ( 30 patients) or within two weeks of the start of treatment (10 patients). Patients were judged to have clinically active nephritis if they showed the presence of either active urinary sediment, proteinuria (over $500 \mathrm{mg} /$ day), or an increased serum creatinine concentration greater than $124 \mu \mathrm{mol} / 1$.

\section{DNA PREPARATIONS}

Double stranded DNA prepared from calf thymus DNA (Sigma) was purified by methylated albumin kieselguhr chromatography ${ }^{16}$ and S1 nuclease treatment. ${ }^{17}$ Single stranded DNA was prepared by heating a $0.1 \mathrm{mg} / \mathrm{ml}$ solution of dsDNA in phosphate buffered saline (PBS), pH $7 \cdot 2$, for 15 minutes at $100^{\circ} \mathrm{C}$ followed by rapid cooling in an ice bath.

\section{DOUBLE STRANDED DNA COATED MICROTITRE} PLATES

Methylated bovine serum albumin (BSA) (10 
$\mu \mathrm{g} / \mathrm{ml})$ was incubated in Immulon type I flat bottomed microtitre plates (Dynatech Laboratories, Alexandria, VA, USA) and, after rinsing with PBS, $0.2 \mathrm{ml}$ dsDNA solution $(2.5 \mu \mathrm{g} / \mathrm{ml})$ in PBS was added, and was incubated for 18 hours at $5^{\circ} \mathrm{C}$. After incubation the dsDNA solution was decanted and $0.3 \mathrm{ml}$ gelatin solution $(1 \mathrm{mg} / \mathrm{ml})$ was incubated in the wells for at least 18 hours. Just before use, the immobilised DNA was redigested with S1 nuclease solution at $4 \mathrm{U} / \mathrm{ml}$ in $0.03 \mathrm{M}$ sodium acetate buffer, $\mathrm{pH} 4 \cdot 4$, containing $0.1 \mathrm{M} \mathrm{NaCl}$, $1 \mathrm{mM} \mathrm{ZnCl}_{2}$, and $100 \mu \mathrm{g} / \mathrm{ml}$ BSA (Cohn's fraction V, Sigma). After four hours shaking at room temperature the wells were rinsed twice with PBS containing 0.05\% Tween 20 (PBSTween).

\section{SINGLE STRANDED DNA COATED MICROTITRE} PLATES

In Immuron type I plates $0.2 \mathrm{ml}$ ssDNA solution $(10 \mu \mathrm{g} / \mathrm{ml}$ in PBS, $\mathrm{pH} 7 \cdot 2)$ was incubated for 18 hours. After incubation the wells were coated with gelatin solution as described earlier.

\section{STANDARD ANTIBODIES TO DOUBLE STRANDED} AND SINGLE STRANDED DNA

Plasma was obtained from a patient with typical clinical and serological features of SLE who had received plasmapheresis. One hundred millilitres of plasma was applied to dsDNA-cellulose chromatography plates (Sigma), washed with PBS until the absorbance of the wash at $280 \mathrm{~nm}$ returned to baseline, and subsequently eluted by increasing the salt concentration in the PBS. ${ }^{18}$ The peaks at $280 \mathrm{~nm}$ were pooled and dialysed against PBS. The concentrations of IgG and IgM in the eluates were determined by the radial immunodiffusion method. Antibodies to ssDNA were isolated as described earlier using ssDNA-cellulose chromatography (Sigma). ${ }^{18}$ These antibodies to dsDNA and ssDNA were used as standard antibodies for the ELISA.

\section{ENZYME LINKED IMMUNOSORBENT ASSAY}

The assays for antibodies to dsDNA were performed on dsDNA coated microplates, and for the determination of antibodies to ssDNA, ssDNA coated plates were used. The two assays were performed according to the methods described by Rubin et al. ${ }^{12}$ Briefly, wells were washed twice with PBS-Tween and $0.2 \mathrm{ml}$ serum, diluted I:200 in PBS-Tween containing $5 \mathrm{mg} / \mathrm{ml}$ bovine gammaglobulin (BGG, Cohn's fraction II, Sigma), $1 \mathrm{mg} / \mathrm{ml} \mathrm{BSA}$, and $1 \mathrm{mg} / \mathrm{ml}$ gelatin, were added. After two hours of incubation with agitation, the contents were removed by aspiration and the wells were washed three times with PBS-Tween. Peroxidase conjugated rabbit antihuman IgG, or IgM (Dakopatts, Copenhagen, Denmark) was diluted 1:400 in PBS-Tween containing $5 \mathrm{mg} / \mathrm{ml} \mathrm{BSA}$ and $1 \mathrm{mg} / \mathrm{ml} \mathrm{BGG}$, and $0.2 \mathrm{ml}$ was added to each well. After agitation at room temperature for two hours the wells were rinsed once with PBSTween and twice with PBS. A $0.2 \mathrm{ml}$ aliquot of substrate solution, containing $1 \mathrm{mg} / \mathrm{ml}$ 2,2-azino-di-(3-ethylbenzthiazoline- $\beta$-sulphonic acid) (Sigma) and $0.005 \% \mathrm{H}_{2} \mathrm{O}_{2}$ in McIlvaine's buffer, $\mathrm{pH} 4 \cdot 6$, was added. The absorbance was determined after 30 minutes using a Titertek multiscan spectrophotometer at $414 \mathrm{~nm}$. For each assay a standard curve was established using a purified known amount of antibodies to dsDNA and ssDNA as a standard antibody.

\section{CRITHIDIA LUCILIAE IMMUNOFLUORESCENCE}

TEST

A standard indirect immunofluorescence technique was employed, ${ }^{19}$ using slides prepared with Crithidia luciliae (Kainos, Tokyo, Japan). FITC conjugated antihuman IgG (Dakopatts) was used for staining. Serum specimens were screened with an initial serum dilution of $1: 10$ in twofold dilutions.

\section{RENAL HISTOLOGY}

The specimens for light microscopy were fixed in buffered formalin solution and embedded in paraffin. The following stains were used: haematoxylin-eosin, periodic acid-Schiff, and Masson's trichrome. World Health Organisation (WHO) criteria were used for the light microscopy classification of the major forms of lupus nephritis ${ }^{20}$ as class I (minor abnormality), class II (mesangial alteration), class III (focal proliferative), class IV (diffuse proliferative), and class $\mathrm{V}$ (membranous). Histological features were scored according to renal activity and chronicity indices. ${ }^{21}$ Individual pathological changes were scored on a semiquantitative basis $(0-3+)$. The activity index was defined as the sum of individual scores of the following items: glomerular cell proliferation, leucocyte exudation, karyorrhexis/fibrinoid necrosis $(\times 2)$, cellular crescents $(\times 2)$, hyaline deposits, and interstitial inflammation. The chronicity index consisted of the sum of individual scores of the following items: glomerular sclerosis, fibrous crescents, tubular atrophy, and interstitial fibrosis.

For electron microscopy the specimens were fixed in $2.5 \%$ glutaraldehyde, postfixed in $2 \%$ osmium tetroxide, dehydrated in graded alcohol, and embedded in epoxy resin. Ultrathin sections were stained with uranyl acetate

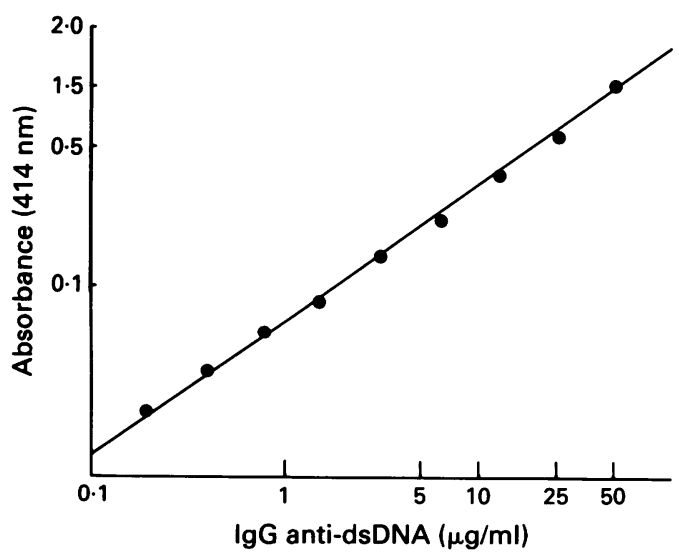

Figure 1 Standard curve established in an assay for IgG anti-dsDNA by enzyme linked immunosorbent assay (ELISA). 
Table 1 Incidence of abnormal laboratory data according to histological classification in patients with lupus nephritis

\begin{tabular}{|c|c|c|c|c|c|c|}
\hline \multirow[t]{2}{*}{ Laboratory parameter } & \multicolumn{6}{|l|}{ Class* } \\
\hline & $\begin{array}{l}I \\
(n=5)\end{array}$ & $\begin{array}{l}I I \\
(n=12)\end{array}$ & $\begin{array}{l}I I I \\
(n=5)\end{array}$ & $\begin{array}{l}I V \\
(n=15)\end{array}$ & $\begin{array}{l}V \\
(n=3)\end{array}$ & $\begin{array}{l}\text { Total } \\
(n=40)\end{array}$ \\
\hline $\begin{array}{l}\text { Haematuria/leucocyturia } \\
\text { Proteinuria } \\
\text { Nephrotic syndrome } \\
\text { Renal insufficiency } \\
\text { IgG antibodies to dsDNA positive by CL-IFT } † \\
\text { IgG antibodies to dsDNA positive by ELISA† } \\
\text { IgM antibodies to dsDNA positive by ELISA† } \\
\text { IgG antibodies to ssDNA positive by ELISA } \\
\text { IgM antibodies to ssDNA positive by ELISA }\end{array}$ & $\begin{array}{l}0 \\
0 \\
0 \\
0 \\
1 \\
4 \\
3 \\
4 \\
5\end{array}$ & $\begin{array}{r}3 \\
4 \\
0 \\
0 \\
5 \\
12 \\
10 \\
10 \\
7\end{array}$ & $\begin{array}{l}2 \\
3 \\
0 \\
0 \\
3 \\
5 \\
5 \\
5 \\
3\end{array}$ & $\begin{array}{r}7 \\
12 \\
8 \\
3 \\
14 \\
15 \\
14 \\
14 \\
10\end{array}$ & $\begin{array}{l}1 \\
3 \\
2 \\
0 \\
1 \\
3 \\
3 \\
3 \\
3\end{array}$ & $\begin{array}{r}13 \\
22 \\
10 \\
3 \\
24 \\
39 \\
35 \\
36 \\
28\end{array}$ \\
\hline
\end{tabular}

${ }^{*}$ According to WHO morphological classification, class $I=$ minor abnormality, class $I I=$ mesangial alteration, class $I I I=$ focal proliferative nephritis, class IV = diffuse proliferative nephritis, and class $V=$ membranous nephritis.

tCL-IFT=Crithidia luciliae immunofluorescence test; ELISA = enzyme linked immunosorbent assay.

and lead citrate. Based on the examination of electron micrographs of multiple areas, the amount of overall electron dense deposit was semiquantitated on a scale of 0 to $3+$ by modification of the method of Grishman et al. ${ }^{22}$

\section{NORMAL CONTROLS}

Serum samples from $\mathbf{4 0}$ healthy laboratory staff were collected and assayed in the same way as the patients' serum samples.

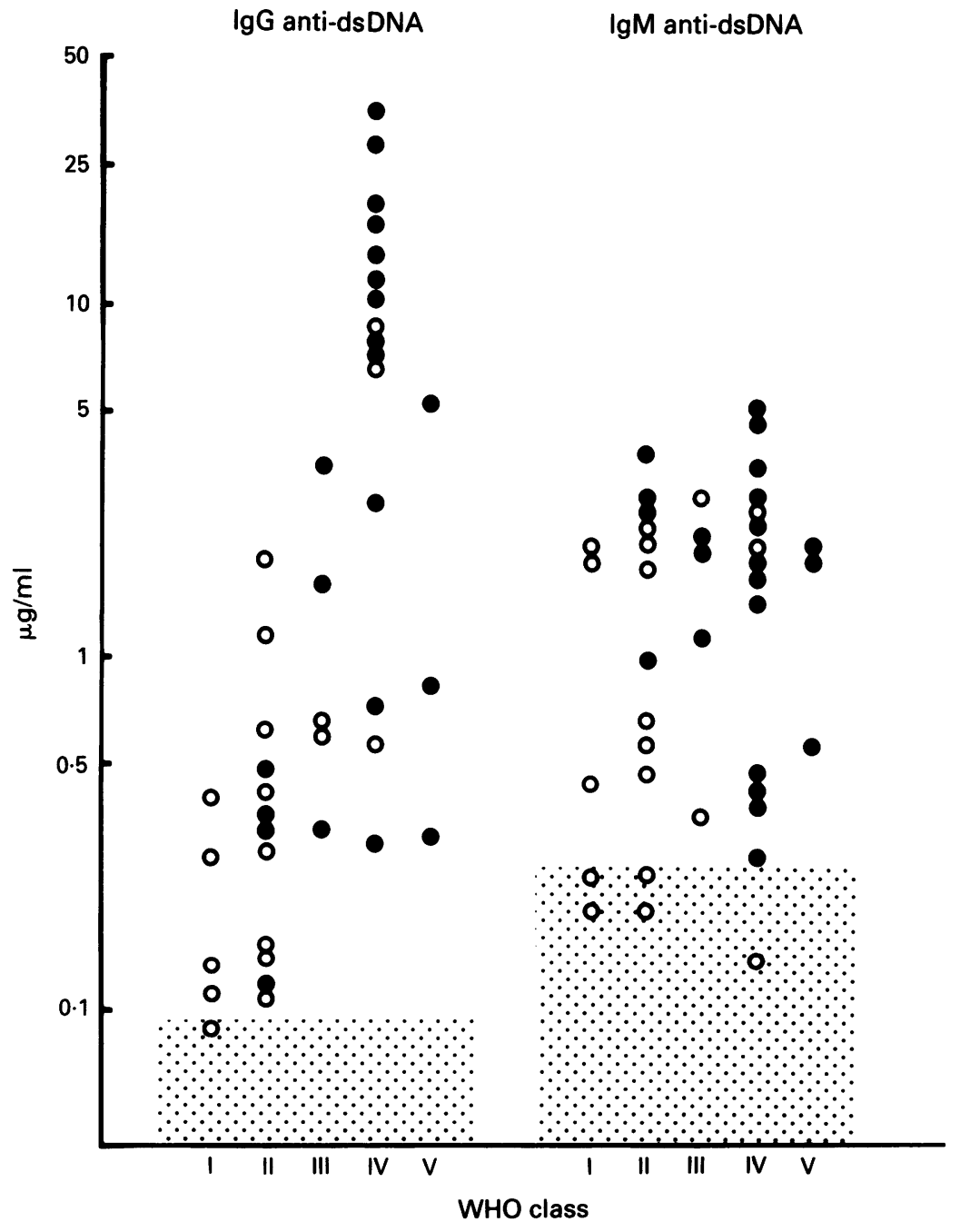

Figure 2 Correlations of IgG and IgM anti-dsDNA with histological classes of lupus nephritis. Significant differences were noted between class I and class IV $(p<0 \cdot 01)$, class II and class IV $(p<0 \cdot 001)$, and class III and class IV ( $p<0 \cdot 01)$ for IgG anti-dsDNA For IgM anti-dsDNA no difference was shown between histological classes. (O) indicates patients with clinically active nephritis. (O) indicates patients without clinically active nephritis. Dotted zones mean normal ranges for IgG and IgM to anti-dsDNA.

\section{STATISTICS}

The statistical significance of the results was evaluated by an analysis of variance (ANOVA) and if significant differences were found by the analysis $p$ values were determined by Duncan's multiple range comparison test. An unpaired Student's $t$ test was also used where appropriate. To determine correlation coefficient values the non-parametric rank order correlation method of Spearman was used. All values were expressed as the mean (SD).

\section{Results}

Figure 1 shows the linearity of a typical standard graph with the ELISA IgG antibody to dsDNA. The IgM antibodies to dsDNA, IgG antibodies to ssDNA, and IgM antibodies to ssDNA standard curves were equally satisfactory. An upper limit of normal was set arbitrarily at two standard deviations above the mean of the values for $\mathbf{4 0}$ healthy controls.

Table 1 lists the laboratory features at the time of the collection of serum samples in which the renal histology was classified according to the WHO classification. Of the 40 untreated patients $22(55 \%)$ had clinical symptoms of active nephritis, whereas 38 patients $(95 \%)$ presented histological abnormalities (three patients with class I nephritis showed abnormalities by electron microscopy). Although most of the patients in classes I and II showed little or no haematuria or proteinuria, or both, four patients showed substantial proteinuria. Three patients who had class IV lupus nephritis with diffuse proliferative lesions and prominent electron dense deposits showed no haematuria or proteinuria.

By the ELISA, 39 (98\%) patients were positive for IgG antibodies to dsDNA, $35(88 \%)$ were positive for IgM antibodies to dsDNA, 36 $(\mathbf{9 0 \%})$ were positive for IgG antibodies to ssDNA, and $28(70 \%)$ were positive for $\operatorname{IgM}$ antibodies to ssDNA. Although the levels of IgG antibodies to dsDNA were highly correlated with the titres of the Crithidia luciliae immunofluorescence test $\left(r_{s}=0.960 ; p<0.001\right)$, the sensitivity is much better for the ELISA $(97 \cdot 5 \%)$ than for the immunofluorescence test $(67 \cdot 5 \%)$.

Figure 2 gives the concentrations of IgG and IgM antibodies to dsDNA with their histological classes. The levels of antibodies to dsDNA in class IV were higher than those in class I 
Table 2 Comparison of antibodies to DNA between renal histological classes. Values given as mean (SD) ( $\mu g / m l)$

\begin{tabular}{|c|c|c|c|c|c|c|c|}
\hline \multirow[t]{2}{*}{$\begin{array}{l}\text { Renal } \\
\text { histology }\end{array}$} & \multirow[t]{2}{*}{$\begin{array}{l}\text { No of } \\
\text { patients }\end{array}$} & \multirow[t]{2}{*}{$\begin{array}{l}\text { IgG antibodies } \\
\text { to dsDNA }\end{array}$} & \multirow{2}{*}{$\begin{array}{l}\text { IgM antibodies } \\
\text { to dsDNA }\end{array}$} & \multirow{2}{*}{$\begin{array}{l}\text { IgM antibodies } \\
\text { to } d s D N A \\
\operatorname{Ig} G \text { antibodies } \\
\text { to } d s D N A\end{array}$} & \multirow{2}{*}{$\begin{array}{l}\text { IgG antibodies } \\
\text { to ssDNA }\end{array}$} & \multirow[t]{2}{*}{$\begin{array}{l}\text { IgM antibodies } \\
\text { to ssDNA }\end{array}$} & \multirow{2}{*}{$\begin{array}{l}\text { IgM antibodies } \\
\text { to ssDNA } \\
\text { IgG antibodies } \\
\text { to ssDNA }\end{array}$} \\
\hline & & & & & & & \\
\hline $\begin{array}{l}\text { Class I } \\
\text { Class II } \\
\text { Class III } \\
\text { Class IV } \\
\text { Class V } \\
\text { Classes I and II } \\
\text { Classes III and IV }\end{array}$ & $\begin{array}{r}5 \\
12 \\
5 \\
15 \\
3 \\
17 \\
20\end{array}$ & $\begin{array}{l}0.19(0.13) \\
0.52(0.50) \\
1.33(1.16) \\
11.59(9.9)^{*} \dagger \\
2.09(2.15) \\
0.42(0.46) \\
9.02(9.94) \ddagger\end{array}$ & $\begin{array}{l}0.99(0.86) \\
1.56(1.17) \\
1.55(0.68) \\
2.03(1.50) \\
1.46(0.72) \\
1.39(1.12) \\
1.88(1.35)\end{array}$ & $\begin{array}{l}7.12(7.88) \\
4.68(4.68) \\
1.94(1.40) \\
0.26(0.29) \\
0.98(0.69) \\
5.40(5.91) \\
0.71(1.03) \ddagger\end{array}$ & $\begin{aligned} 2.44(1.53) \\
2.70(1.85) \\
3.80(3.01) \\
11.85(18.69) \\
2.16(0.85) \\
2.62(1.77) \\
9.84(16.62)\end{aligned}$ & $\begin{array}{l}0.74(0.47) \\
0.79(0.83) \\
0.54(0.32) \\
0.73(0.65) \\
1.44(0.84) \\
0.78(0.76) \\
0.69(0.59)\end{array}$ & $\begin{array}{l}0.81(0.90) \\
1.26(3.12) \\
0.25(0.09) \\
0.14(1.40) \\
0.62(1.28) \\
1.12(2.68) \\
0.17(0.16)\end{array}$ \\
\hline
\end{tabular}

${ }^{*} \mathrm{p}<0.01 v$ class $\mathrm{I}$, class III, by Duncan's test. $\dagger \mathrm{p}<0.001 v$ class II, by Duncan's test.

$\ddagger \mathrm{p}<0.01 v$ classes I and II, by Student's $t$ test.

$\$ \mathrm{p}<0.05 v$ class II, by Duncan's test.

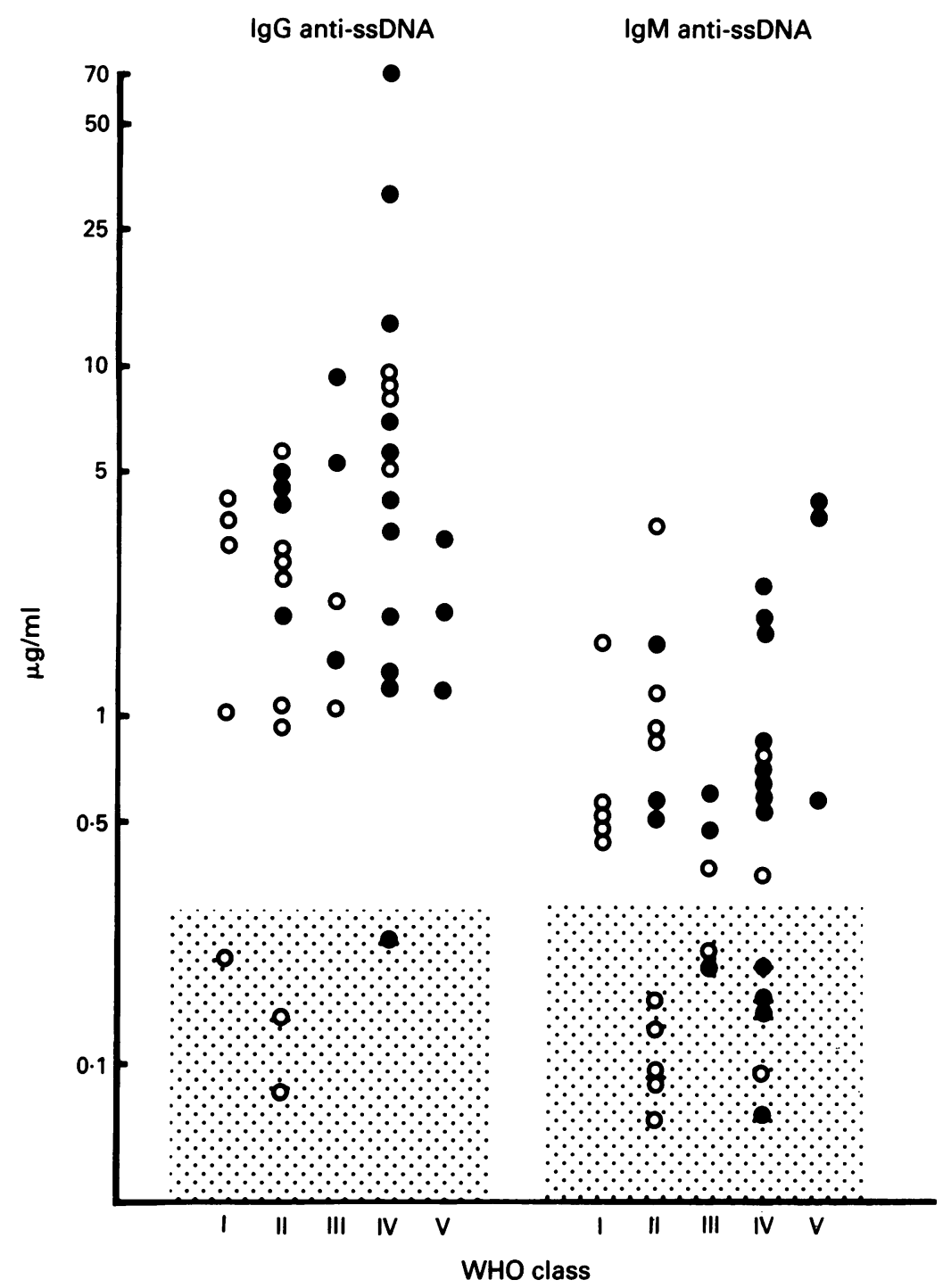

Figure 3 Correlations of IgG and IgM anti-ssDNA with histological classes of lupus nephritis. A significant difference was noted between class II and class IV $(p<0.05)$ for IgG anti-ssDNA. No difference was shown between histological classes for IgM anti-ssDNA

(O) indicates patients with clinically active nephritis. $(O)$ indicates patients without clinically active nephritis. Dotted zones mean normal ranges for IgG and IgM to anti-ssDNA.

Table 3 Rank order correlations between renal histology and antibodies to DNA

\begin{tabular}{|c|c|c|c|c|}
\hline & $\begin{array}{l}\text { Activity } \\
\text { score }\end{array}$ & $\begin{array}{l}\text { Chronicity } \\
\text { score }\end{array}$ & $\begin{array}{l}\text { Total } \\
\text { pathological } \\
\text { score }\end{array}$ & $\begin{array}{l}\text { Electron } \\
\text { dense } \\
\text { deposits }\end{array}$ \\
\hline $\begin{array}{l}\text { IgG antibodies to dsDNA } \\
\text { IgM antibodies to dsDNA } \\
\text { IgG antibodies to ssDNA } \\
\text { IgM antibodies to ssDNA }\end{array}$ & $\begin{array}{l}0 \cdot 741^{* *} \\
0 \cdot 268 \\
0 \cdot 434^{* *} \\
0 \cdot 168\end{array}$ & $\begin{array}{l}0.407^{\text {*: }} \\
0.113 \\
0.368^{\text {**: }} \\
-0.079\end{array}$ & $\begin{array}{l}0 \cdot 710^{*} \\
0 \cdot 249 \\
0 \cdot 448 \\
0 \cdot 073\end{array}$ & $\begin{array}{l}0 \cdot 810^{\text {*: }} \\
0 \cdot 308 \\
0 \cdot 446 \\
0 \cdot 212\end{array}$ \\
\hline
\end{tabular}

${ }^{*} \mathrm{p}<0.05 ;{ }^{*} \mathrm{p}<0.01$. $(\mathrm{p}<0.01)$, class II $(\mathrm{p}<0.001)$, and class III $(\mathrm{p}<0.01)$, though there was a dispersion of levels among the classes. The patients with clinical symptoms of nephritis had a higher mean (SD) level of IgG antibodies to dsDNA $(7.80(9.98) \mu \mathrm{g} / \mathrm{ml})$ than in those without clinical symptoms of nephritis $(1 \cdot 12 \quad(2 \cdot 47)$ $\mu \mathrm{g} / \mathrm{ml})(\mathrm{p}<0.01)$. No difference was found among patients with different histological classes in the levels of IgM antibodies to dsDNA. Figure 3 gives the correlations of IgG and IgM antibodies to ssDNA with the histological classes. The levels of IgG antibodies to ssDNA in patients with class IV nephritis were higher than those in patients with class II nephritis $(p<0.05)$. The patients with clinical symptoms of nephritis had higher levels of IgG antibodies to ssDNA than those without clinical symptoms of nephritis $(8.79(16.43) \mu \mathrm{g} / \mathrm{ml} v$ $3.04(2.69) \mu \mathrm{g} / \mathrm{ml} ; \mathbf{p}<0.05)$. No difference was found among patients with different histological classes in the levels of IgM antibodies to ssDNA. Table 2 gives all the data for comparison of antibodies to DNA among renal histological classes. The levels of IgG antibodies to dsDNA were significantly higher in patients with moderate to severe nephritis (class III and class IV) than those with mild nephritis (class I and class II), whereas there was no difference between the two groups in the levels of IgM antibodies to dsDNA. The geometric mean ratio of IgM antibodies to dsDNA/IgG antibodies to dsDNA was significantly lower in patients with moderate to severe nephritis than in those with mild nephritis $(p<0.01)$.

Table 3 gives results of the Spearman rank order correlation of antibodies to dsDNA and ssDNA with the renal activity score, chronicity score, and total pathological score by light microscopy and with the overall electron dense deposits. Correlation for IgG antibodies to dsDNA with each of the histological scores was good, with that for electron dense deposits being the best and activity score being the second best $\left(r_{s}=0.810 ; p<0.01 ; r_{s}=0.741\right.$; $p<0.01$ respectively) (figs 4 and 5). Correlations for IgG antibodies to ssDNA with each of the parameters were weak. IgM antibodies to dsDNA and IgM antibodies to ssDNA were not correlated with those parameters. There was a weak correlation between the level of IgG antibodies to dsDNA and IgG antibodies to ssDNA $(r=0.394 ; p<0.01)$. There were three 


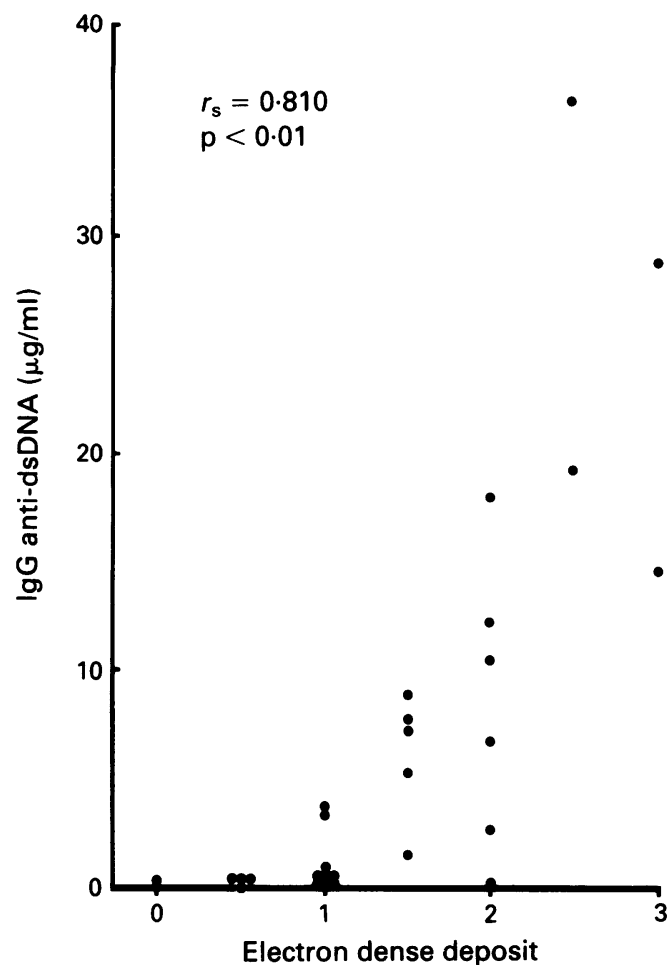

Figure 4 Close correlation of IgG anti-dsDNA with renal histological activity score. Correlation coefficient by Spearman rank order analysis is indicated by $r_{s}$ value.

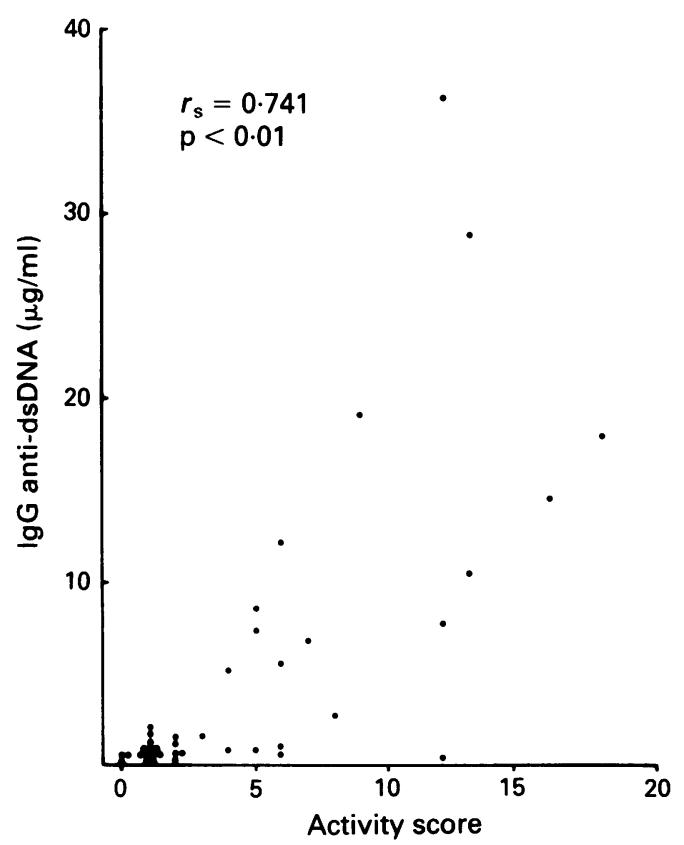

Figure 5 Close correlation of IgG anti-dsDNA with amount of overall electron dense deposits. Correlation coefficient by Spearman rank order analysis is indicated by $r_{s}$ value.

patients with class IV nephritis with relatively low IgG antibodies to dsDNA and high levels of IgG antibodies to ssDNA.

\section{Discussion}

We measured the levels of IgG antibodies to dsDNA, IgM antibodies to dsDNA, IgG antibodies to ssDNA, and IgM antibodies to ssDNA by ELISA in the serum samples of untreated patients with SLE whose renal histo- logical severities were assessed. Measurements for antibodies to DNA have been considered as useful in the management of patients with SLE because of their diagnostic specificity and their probable correlation with disease activity. It has been reported that the levels of antibodies to dsDNA correlate with renal disease in patients with SLE, ${ }^{15-7} 10$ but not all studies are in agreement with these reports. ${ }^{89}$ These results should be interpreted with some caution. First, the antibodies to dsDNA were often measured with the use of conventional dsDNA antigen which is thought to be nearly always contaminated with ssDNA. ${ }^{23}$ Chromatographically purified and S1 nuclease treated dsDNA preparations are considered operationally native. ${ }^{11} 12$ This view was supported by the results in this study that the levels of IgG antibodies to dsDNA were highly correlated with the titres of Crithidia luciliae immunofluorescence test $\left(r_{s}=0.96 ; p<0.001\right)$. As it has been shown that the antigenicity of $\mathrm{dT}-\mathrm{dA}$ is different from that of dsDNA, ${ }^{24}$ the purified dsDNA preparation used in this study is thought to be more suitable to detect antibodies to dsDNA. Second, interpretation of the data on antibodies to dsDNA may be misleading without renal biopsy data. In this study the incidence of clinically active nephritis was $55 \%$, whereas renal histological abnormalities were found in $95 \%$ of patients. There were three patients with class IV lupus nephritis who showed no clinical symptoms of renal disease. Discrepancies between clinical data and renal histological features have been reported by other workers. ${ }^{25-27}$ Thirdly, as it is likely that adequate immunosuppressive treatment induces rapid changes in serum levels of antibodies to DNA and changes in renal histological features, data obtained from the untreated patients with SLE are particularly important.

In the present study increased levels of IgG antibodies to dsDNA were found in $98 \%$ of untreated patients with SLE, and a similar high incidence has been reported by other workers using ELISAs. " We found that the levels of IgG antibodies to dsDNA in patients with class IV nephritis were significantly higher than those of patients with classes I, II, and III, nephritis. Although other workers have reported that antibodies to dsDNA, detected by the conventional dsDNA preparation, in patients with diffuse proliferative nephritis were higher than those in patients with focal and segmental nephritis, the difference was not clear and not statistically significant. ${ }^{28}$ Clough and Valenzuella showed that patients with diffuse proliferative nephritis had a higher ratio of IgM to IgG antibodies to DNA than those with focal nephritis, even though the total amount of antibody to DNA was the same in the two groups. ${ }^{29}$ Others have reported that the ratio of IgG to IgM antibodies to dsDNA did not significantly differ in patients with active nephritis and in patients without clinical evidence of renal disease. ${ }^{30} 31 \mathrm{We}$ tried to compare the ratio of IgM to IgG antibodies to dsDNA between patients with histologically mild nephritis (class I and class II) and those with moderate to severe nephritis (class III and class IV). The ratio of 
IgM to IgG antibodies to dsDNA was significantly lower in patients with moderate to severe nephritis than in those with mild nephritis. These results may be explained by the fact that the levels of IgG antibodies to dsDNA were significantly higher in patients with moderate to severe nephritis than in those with mild nephritis, whereas the levels of IgM antibodies to dsDNA were the same in the two groups. Our results are consistent with the results of Pennebaker et al who reported that patients with predominantly $\operatorname{IgG}$ antibodies to dsDNA showed more severe histological changes. ${ }^{31}$ These findings are also compatible with the report that immunoglobulin deposition in lupus nephritis, detected by immunofluorescence, and antibodies to DNA, eluted from the kidneys of patients with severe lupus nephritis, were primarily IgG. ${ }^{14}$

Owing to the marked variability of lupus nephritis, we used a semiquantitative scoring system and assessed the correlation with antibodies to dsDNA. We found a significant correlation between the levels of IgG antibodies to dsDNA and each of the histological parameters. A previous study, using a conventional dsDNA preparation, showed no correlation between antibodies to dsDNA and renal histological activity. ${ }^{8}$ As the levels of IgG antibodies to dsDNA closely reflect the electron dense deposit as well as the activity score by light microscopy, they may provide useful information to assess the severity of lupus nephritis noninvasively.

Our results support the general view that antibodies to dsDNA play a crucial part in the pathogenesis of lupus nephritis. ${ }^{14} \mathrm{We}$ identified three patients who showed no clinical signs of renal disease and were proved to have class IV lesions. The presence of such patients with clinically occult diffuse proliferative lupus nephritis has also been reported by other workers. ${ }^{26} 27$ As these patients had high levels of IgG antibodies to dsDNA, we suggest that this assay may be helpful in deciding whether a renal biopsy is necessary or not.

The prevalence of antibodies to ssDNA in patients with SLE is high and these antibodies have been thought to be closely correlated with disease activity ${ }^{14}$ data supporting the presence of ssDNA antibodies to ssDNA immune complexes in the affected glomeruli have been reported. ${ }^{3}$ No previous studies have attempted to correlate antibodies to ssDNA with renal histological severity in patients with lupus nephritis. Although we found a weak correlation between IgG antibodies to ssDNA and renal histological severity, the correlation was less clear than that of IgG antibodies to dsDNA. These results are consistent with the general view that ssDNA antibodies to ssDNA immune complexes are not important in the pathogenesis of lupus nephritis. ${ }^{32}$ As we found three patients with class IV lesions who had high levels of IgG antibodies to ssDNA and relatively low levels of IgG antibodies to dsDNA, however, antibodies to ssDNA may play a part in the pathogenesis of nephritis in some patients with lupus.

It has been previously shown that patients whose antibodies precipitate and bind to DNA have a greater incidence of nephritis, ${ }^{33}$ and low avidity antibodies ${ }^{34}$ or complement fixing antibodies $^{35}$ are claimed to be more nephritogenic. Our study, however, suggests that quantitative differences of antibodies to DNA play a major part in determining the histological features of lupus nephritis. Therefore whether qualitative differences in antibodies to DNA critically affects the pathological features of lupus nephritis needs further study.

1 Pincus T, Schur P H, Rose J A, et al. Measurement of DNA binding activity in systemic lupus erythematosus. $N$ Engl Med 1969; 281: 701-5

2 Hughes G R V, Cohen S A, Christian C L. Anti-DNA activity in systemic lupus erythematosus. Ann Rheum Dis 1971; 30 $259-64$.

3 Andres G A, Accinni L, Beiser S M, et al. Localization of fluorescein labeled anti-nucleoside antibodies in glomeruli of patients with systemic lupus erythematosus. $\mathcal{F}$ Clin Invest of patients with system

4 Koffler D, Agnello V, Kunkel H G. Polynucleotide immune complexes in serum and glomeruli of patients with systemic lupus erythematosus. Am F Pathol 1974; 74: 109-24.

5 Schur P H, Sandson J. Immunologic factors and clinical activity in lupus erythematosus. N Engl f Med 1968; 278: 533-8.

6 Ballou S P, Kunshner I. Immunochemical characteristics of antibodies to DNA in patients with active systemic lupus erythematosus. Clin Exp Immunol 1979; 37: 58-67.

7 Chubick A, Sontheimer R D, Gilliam J N, et al. An appraisal of tests for native DNA antibodies in connective tissue disease: clinical usefulness of Crithidia luciliae assay. Ann Intern Med 1978; 89: 186-92.

8 Hill G S, Hinglais N, Tron P, et al. Systemic lupus erythematosus. Morphologic correlation with immunologic and clinical data at the time of biopsy. Am $\mathcal{F}$ Med 1978; 64 61-79.

9 Appel A E, Sablay L B, Golden R A, et al. The effect of normalization of serum complement and anti-DNA antibody on the course of lupus nephritis. Am $\mathcal{F}$ Med 1978; 64: 274-83.

10 Steinman C R, Grishman E, Spiera $\mathrm{H}$, et al. Binding of synthetic double stranded DNA by serum from patients with systemic lupus erythematosus. Correlation with rena histology. Am F Med 1977; 62: 319-23.

11 Miller T E, Lahita R G, Zarro V J, et al. Clinical significance of anti-double stranded DNA antibodies detected by a solid phase enzyme immunoassay. Arthritis Rheum 1981; 24: 602-10.

12 Rubin R L, Joslin F G, Tan E M. An improved ELISA for anti-native DNA by elimination of interference by antianti-native DNA by elimination of interference by anti-

13 Gripenberg M, Linder E, Kurki P, et al. A solid phase enzyme-linked immunosorbent assay (ELISA) for the demonstration of antibodies against denatured, single stranded DNA in patient sera. Scand $\mathcal{F}$ Immunol 1978; 7 151-7.

14 Koffler D, Schur P H, Kunkel H G. Immunological studies concerning the nephritis of systemic lupus erythematosus. $\mathcal{F} \operatorname{Exp} M$ Med 1967; 126: 607-23.

15 Tan E M, Cohen A S, Fries J F, et al. The 1982 revised criteria for the classification of systemic lupuserythematosus. Arthritis Rheum 1982; 25: 1271-7.

16 Winfield J B, Faiferman I, Koffler D. Avidity of anti-DNA antibodies in serum and IgG glomerular eluates from patients with systemic lupus erythematosus. $\mathcal{F}$ Clin Inves 1977; 59: 90-6.

17 Kloz J L, Minami R M, Teplitz R L. An enzyme-linked immunosorbent assay for antibodies to native and denatured DNA. F Immunol Methods 1979; 29: 155-65.

18 Albert B, Herrick G. DNA-cellulose chromatography. In: Grossman L, Moldave $\mathrm{K}$, eds. Nucleic acids part $D$, Methods in Enzymology. Vol. XXI. New York: Academic Methods in Enzymolog.

19 Sontheimer R D, Gilliam J N. An immunofluorescence assay for double-stranded DNA antibodies using the Crithidia luciliae kinetoplast as a double-stranded DNA substrate. f Lab Clin Med 1978; 91: 550-9.

20 Churg J. Renal disease. Classification and atlas of glomerular disease. Tokyo: Igaku-Shoin, 1982, 127-49.

21 Austin H A, Muenz L R, Joyce K M, et al. Diffuse proliferative lupus nephritis: identification of specific
pathologic features affecting renal outcome. Kidney Int pathologic features

22 Grishman E, Porush J G, Churg J, et al. Renal biopsies in lupus nephritis: correlation of electron microscopic findings with clinical course. Nephron 1973; 10: 25-36.

23 Steinman C R, Deesomchok K U, Spiera H, et al. Detection of anti-DNA antibody using synthetic antigens. $\mathcal{J}$ Clin Invest 1976; 57: 1330-41.

24 Gilliam A C, Lang D, Lospalluto J J, et al. Antibodies to double-stranded DNA: purification and characterization of binding specificities. $\mathcal{F}$ Immunol 1980; 125: 874-85.

25 Rothdield N J, McLuskey R J, Baldwin D S, et al. Rena disease in systemic lupus erythematosus. $N$ Engl $\mathcal{f} M e d$ 1963; 269: 537-44. 
26 Mahajan S K, Ordonez N G, Feitelson P J, et al. Lupus nephropathy without clinical renal involvement. Medicine (Balitimore) 1977; 56: 493-501.

27 Eiser A R, Katz S M, Schwartz C, et al. Clinical occult diffuse proliferative lupus nephritis. Arch Intern Med 1979, 139: 1022-5.

28 Tron F, Bach J F. Relationships between antibodies to native DNA and glomerulonephritis in systemic lupus erythema-

29 Clough J D, Valenzuella R. Relationship of renal histopathology in SLE nephritis to immunoglobulin class of anti-DNA. Am F Med 1980; 68: 80-5.

30 Feldman M D, Huston D P, Karsh J, et al. Correlation of serum IgG, IgM and anti-native DNA antibodies with renal clinical indexes of activity in systemic lupus erythematosus. F Rheumatol 1982; 9: 52-8.

31 Pennebaker J B, Gillian J N, Ziff $\mathbf{M}$, et al. Immunoglobulin classes of DNA binding activity in serum and skin in systemic lupus erythematosus. $\mathcal{f}$ Clin Invest 1977; 60: 1331-8.

32 Koffler D, Agnello V, Winchester R V, et al. The occurrence of single-stranded DNA in the serum of patients with systemic lupus erythematosus and other disease. $\mathcal{F}$ Clin Invest 1973; 52: 198-204.

33 Edmonds J P, Johnson G D, Ansell B M, et al. The value of tests for antibodies to DNA in monitoring the clinical course of SLE: a long-term study using the Farr test and the DNA counter immunoelectrophoretic method. Clin Exp Immunol 1975; 24: 9-15.

34 Leon S A, Green A, Ehrlich G E, et al. Avidity of antibodies in SLE. Relations to severity of renal involvement. Arthritis Rheum 1977; 20: 23-9.

35 Beaulieu A, Quismorio F P Jr. Kitridou R C, et al. Complement fixing antibodies to dsDNA in systemic lupus erythematosus: a study using the immunofluorescen Crithidia luciliae method. $\mathcal{F}$ Rheumatol 1979; 6: 389-96. 